\title{
BIM strategy: using the project's interdisciplinarity to implement the methodology
}

\author{
Juliana A. Mizumoto ${ }^{1 *}$ and Francisco Oliveira ${ }^{2}$ \\ 1,2 CIAUD, Faculdade de Arquitetura, Universidade de Lisboa, Lisboa, Portugal;
}

\begin{abstract}
.
The Civil Construction Industry has demonstrated convergence for the paths of new technologies, digitization, and new work processes that are inherent to the Building Information Modeling (BIM) methodology. In this sense, there is a growing interest by engineering organizations in BIM implementation and the development of studies about the method to adapt to the new dynamics of the industry. A point of interest is the focus on the work processes of companies, standards, and guidelines to explore this subject, but which is not always transparent in identifying the first steps or actions for their execution practice.

The methodology of this paper incorporates knowledge from specific literature, norms, and industry guides to support and suggest a method for BIM implementation. As a result of this research, we recommend a structured method for customizing and meeting the organization's requirements. Through a case study, this method addresses project management and selects essential planning elements for a BIM implementation. This experience was part of a BIM Implementation Plan developed by the author. This paper displays it as a pilot project for a Portuguese organization specializing in significant infrastructure works, adapting the industry documents to the strategic and implementation dimensions of BIM.

The methodology established for five months of project execution identified several strategic topics to begin the BIM implementation, such as the initial standardization of the information and the surveillance of the learning dynamics of the project team.
\end{abstract}

Keywords: Building Information Modeling, BIM implementation, BIM work processes, BIM Pilot Project

\section{Introduction}

The use of BIM methodology, its implementation, and its results have been monitored for at least a decade(NBS, 2019). Specific literature records are extensive, and, in this paper, 


\section{8 - 20 September, 2020 MILAN, ITALY}

we uncover an alternative approach regarding a custom implementation applied to a case study.

This research is part of a BIM implementation pilot project, which comprises with a BIM Implementation Plan (BIMPI), and its evaluation is structured as follows: (i) situational analysis of the BIM implementation, through specific literature; (ii) organization of a project plan; (iii) exposure of a structured and applied methodology.

\subsection{BIM Implementation}

In addition to a work methodology, BIM represents a new mode of thinking, that changes the interactions in the Architecture, Engineering, and Construction (AEC) sector. The sector starts to use the digital model as the basis for the information management throughout the life cycle of a project, as well as for sharing information and data, among participants, through a transparent communication process (Digital Infrastructure, 2015), making it possible to digitally coordinate the results related to all projects(EUBIM Task Group, 2016).

Several studies point out the benefits of the BIM methodology with different approaches, such as use in project companies, which generates exciting discussions about work practices, adjustments in the design process, and team relationships(Eastman, 2011). Besides, there is an association with other gains, such as developing multiple design alternatives, improving document distribution, and clarifying representation (Azhar, 2011). Furthermore, the use of the methodology in the AEC industry induces the project interdisciplinarity and the enhancement in the description of ideas, improving the final quality of the as-built documentation (Arayici et al., 2012), also contributing to the strengthening of the correlation between project and costs, improving the simulations and the global performance of projects (Navendren et al., 2014).

The ability of BIM methodology to offer economical and sustainable benefits, reaching a varied and extensive number of participants from the public sector, to the private sector is currently (EUBIM Task Group, 2016) According to a 2019 study, the financial return, after implementation, was positive in $75 \%$ of the organizations that adopted BIM in the European (Observatory, 2019)

However, the BIM methodology faces some barriers in its implementation, both from the AEC and the project companies. The European AEC industry still resists to the challenges of a widespread disseminating. Only $29 \%$ of the engineering companies used $\mathrm{BIM}$, and $61 \%$ never used that methodology. This panorama is also the result of the fragmentation in the BIM use by the industry, were the most significant investments are made in the project design phase, and not so in the operation and maintenance phases (Observatory, 2019). According to an implementation study made in the United Kingdom (Navendren et al., 2014), the implementation adversities are many, and one can consider that they influence critical areas of an organization: technological, organizational, and environmental. Therefore, the performance of BIM implementation should cover areas of legal policies such as contracts, supplies, project planning, and technical zones such as safety, technical information of the model, quality, and validation. When reaching these areas, the processes are modified, and collaborative work begins, in addition to developing the teams with new training and skills [3]. To encompass all these already recognized 


\section{8 - 20 September, 2020 MILAN, ITALY}

dynamics of the methodology, organize the implementation strategies that aim to understand how internal relations with the actor's networks are developed(Lindblad, 2019).

Because of the challenges placed by planning a BIM implementation, the idea of standardization has been widely discussed in recent years (Arayici et al., 2012; Mahamadu et al., 2017; Wei Wu \& Issa, 2014)and this is a critical point when it comes to deal with the communication between the various stakeholders and interests of the AEC industry (Howard \& Björk, 2008). There are several advantages of setting standards in the sector, and, in the case of BIM, this facilitates the dispersion of initiatives, minimizing costs using existing knowledge. Besides, it allows the interaction between distinctive regions and countries, diminishing cultural barriers, and encouraging the development of interoperable software (Eastman et al., 2011), which are essential in a collaborative methodology.

Today, the BIM implementation is present at different stages, depending on the global region (Observatory, 2019) subject of extensive studies, which explore the differences in its maturity at various countries(McGraw Hill Construction, 2014; Smith, 2014) concluding that its greater or smaller development is also associated with the dissemination of standard plans incentives and initiatives. These initiatives are made visible through multiple communication channels, not only with the AEC sector but also with others such as the academia, software companies, and projects (Ahmad et al., 2012). It also includes government participation as a significant catalyst for implementation (McGraw Hill Construction, 2014) through the incentive translated into laws and standards exposed in the form of guidelines (Chae \& Kang, 2015; EUBIM Task Group, 2016)and procedures detailing critical activities to be developed, which demonstrate effectiveness through case studies and priorities for using BIM (AEC (UK), 2012; BCA Building and Construction Authority, 2013; Digital Infrastructure, 2015).

\subsection{Project Plan}

The need to organize the knowledge structure covering the BIM methodology is already known and recognized. The discussion continues to gain intensity as more private and national organizations recognize its potential and added value(Succar, 2009). Following the argument already exposed, that standardization favors the expansion of BIM uses, published Guidelines are an essential direction for the structuring of a BIM project.

In different ways, but not absent, the guides approach the methodology to create a synergy for the areas, translated by Succar (Succar, 2009) as "fields" (policies, processes, and technology) or areas of BIM action. And, consequently, areas to be measured to identify the level of BIM maturity in a specific organization. Likewise, it presents itself as performance levels (policy, processes, technology, people, and skills) in industry documents (EUBIM Task Group, 2016), or as BIM planning elements (processes, information, strategy, infrastructure, uses, people) (The Pennsylvania State University, 2013).

Considering the BIM areas of action, the implementation process is part of the process, which contains BIM maturity levels goals as objectives. This format is described in the specialized literature(Kassem et al., 2013; Silva et al., 2016). The possibilities of 
interventions are uncovered, but the priorities are unique to each project, and the context applied(Azzouz \& Hill, 2017). The background states that two organizations are always different [20] since they have different types of organizational structures, dimensions, and internal cultures. Therefore, the plan should be designed for specific activities, considering a particular environment, with particular participants, on behalf of a project with precise characteristics [24].

Therefore, the context of a project dictates what should be implemented, and consequently, the involved parties should delineate the organizational levels to be worked. Succar describes it in 12 scales (Succar, 2010), divided into three groups: macro, meso, and micro, going from an international organizational size to the level of team members. This need for definition matches with strategic implementation plans(EUBIM Task Group, 2016; The Pennsylvania State University, 2013) that describe and detail the implementation phases by indicating good practices of setting goals and defining actions in each of them. These actions are initially worked at the strategic level and can be organized from the evaluation of the context. At this stage, priority areas of activity are determined, focusing on the future use of the methodology. Then, proceeds to Alignment, determining the level of implementation and interests of the organization; and, from this point to the design of the implementation progress of the methodology, the moment in which the transition from old processes to new ones, in the organization's business practices, is planned[20].

As well as local standards and laws, existing standards should be considered in an implementation plan. That is another point under the argument about the need to set customized goals for each organization. Standards are motors of studies on the subjects that aim at understanding the similarity between them and, consequently, the context in which they are applied [19], [26]-[28], as a result of translating the reality of each country and the priorities of each place.

In the specific circumstance of projects within the European Community, we quote the documents PAS 11192 and ISO19650 (BSI, 2013; International Organization for Standardization (ISO), 2017) as a way to illustrate the importance and level of commitment between its members, in describing and organizing the idea of planning and working with the BIM methodology. According to these documents, it should be planned from organizational strategies to the level of information exchanges during a project.

\section{Methodology}

The methodology presented in this paper is part of a BIM Implementation Plan that was applied in a case study centered on a Portuguese infrastructure engineering organization. Some organization characteristics were considered crucial for the study: having more than 50 years of work with infrastructure projects in European, African and Asian markets, is specialized in public works, having a management and performance control system applied, and besides, to developing value engineering and investing in process improvement. Due to the long experience of employees in traditional processes and the management of processes in different countries, while maintaining the same company culture and management processes already incorporated, all these characteristics were fundamental to form the initial context for the BIM implementation project. 


\section{8 - 20 September, 2020 MILAN, ITALY}

The proposal consisted of a BIM implementation plan (BIMIP); the participants formed a team of different professionals, from planning, costs, design, engineering, and management areas. It was, therefore, a multidisciplinary team with specific objectives and requirements dictated by the organization: to start the BIM implementation using as a basis a particular project, which was representative of the design and engineering fields, commonly developed by the of the organization within the scope of public contracts. The plan should go beyond both technical aspects and initial employee training.

The applied methodology was based on specialized literature; the plan customization followed the company characteristics and the objectives defined by the organization.

The good practices of project management already followed by the organization and incorporated into BIMIP are those that are advocated by the Project Management Institute (PMI, 2013).

\subsection{Structured Implementation Model}

Implementing BIM from the industry's previous experience is a form already validated, and the comparison between several case studies supports the development of new BIM uses (Shou et al., 2015).

From this, the initial and strategic structuring of the plan was based on related literature(The Pennsylvania State University, 2013). It separated the first approaches toward the organization: Assessment, Alignment, and Advancement. The organization's characteristics are responsible for systematizing the assessment phase. In contrast, the Alignment began with the choice of BIM elements or areas to be worked by the team. The planning elements form the basis of the selection:(1)Processes: new processes for new uses, transition from the old to the original;(2) Information: needs or requirements, level of detail; (3) Strategy: goals and objectives, supports and resources; (4) Infrastructure: software, hardware, network, physical space; (5) Usage: uses of the model to generate, process, communicate, execute and manage; (6) People: establish rules, responsibilities, training and training, new BIM team.

Following, the element selection was approved by the team, in addition to aligning the expectation and understanding of the context of the project, the desired dimension of work to be performed. The knowledge of the extent of the interference that BIM would entail in other areas was also part of this phase.

The advanced phase displays the structured model that expresses the design and describes the primary process and activities that are part of the project execution lifecycle.

\subsection{Strategic customization points}

A strategic point of the implementation process refers to the work on the know-how of the team participants, the dissemination of applied information and translated into knowledge. Based on the theory of diffusion of innovation (Rogers, 2003), the plan was also structured to foster communication and collaboration during the project. As an objective, it is the use of implicit knowledge of each team participant, that is, the knowledge acquired through practice, experience, errors, and successes. It also turns it into explicit knowledge, which the organization and people can document and handle. 


\section{8 - 20 September, 2020 MILAN, ITALY}

This strategy directed the BIMIP to organize the project and exposure activities of implementation progress to consider the time of collaboration required between the team for each project activity.

Following this strategy, the project is divided into three stages of operation: Project Planning, Model Design, and Collaborative Model. The project planning phase consisted of the general planning of how the project would be addressed and the following steps in the team participation in the model execution. The first phase is related to the creation of project parts and testing of modeling tools to define which results fit the requirements. For the collaboration phase, other information inputs are related, such as work planning schedules, integration with Infraworks for proposal presentations and, project evaluation.

The priorities defined in the alignment phase are the basis for the division of the project time operation. They relate to the technical knowledge analyses of the team, and from this, the definition of how to present the activities. The active team participation in the planning model phase and the technical structuring of the model to meet the requirements defined by themselves is an objective of this phase, besides understanding which portions of the project should be modeled, what information to be incorporated, that is, to collaborate actively.

The temporal division was customized; that is, the project phases object changes in this structure proposal depending on the requirements of the organization. The static environment is the division of stages into model working groups, and for each group, BIM activities required for delivery of the final product (Figure 1) have been identified.

\subsection{Working groups and activities}

The framework presented is based on related literature, which reports the organization of BIM information in frameworks,(Succar, 2009), and points to a multidimensional planning trend(W Wu et al., 2018a) for both industry and other areas such as academia or companies(Zhang et al., 2016). The objective was to integrate the BIM areas of interest already described in the literature (State, 2010; W Wu et al., 2018b) to the areas of management in the form of working groups, based on the PMI methodology (PMI, 2013).

The BIMIP begins in the strategic dimension, and the implementation dimension is divided into 3 phases of operation. For each phase there are activities that are subdivided into 10 workgroups: (1) Diagnosis; (2) Training; (3) Systems integration; (4) PEB; (5) Procurement; (6) Processes; (7) Schedule; (8) Modeling; (9) Document Management; (10) Meetings.

The division of workgroups aims to gather the activities necessary for the implementation of the model. This facilitates the understanding of the BIM methodology by the participants in this context of an already existing project management. This strategy aims at an implementation not only, but also of the socio-cultural environment (Coates et al., 2010), as well as encourages the re-engineering and re-evaluation of the working model. These reflections are necessary for BIM implementation(Smith, 2014).

The structured model for the activities presentation operates with the inclusion organized so that the team perceives and evaluates the best tools to perform them, in 


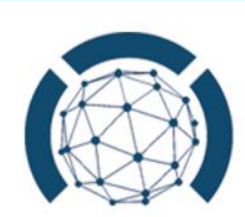

addition to starting the work process structure, reasoning intrinsic to the BIM methodology and that forces participants to work more closely and (Pruskova \& Kaiser, 2019). The activities performed during the project were selected according to the organization's requirements and technically translated into BIM requirements, that is, interpreted as activities necessary to perform the model and deliver the product. Therefore, this BIMIP is a structure that can be reproduced and represents a custom template for an organization that requires a specific product.

The divisions of activities focus on organizing and displaying to the team the actions necessary to complete the product; they are also based on previous studies on BIM implementation difficulties, such as the lack of organization or consideration of hiring during the project process(Migilinskas et al., 2013). This is an essential aspect for any organization, but especially for those who tend to work with large public infrastructure contracts.

Following this reasoning, a structure was created, briefly presented, with examples of activities for each working group in its specific time phase (Figure 1).

\section{Discussion}

The BIMIP applied format allowed the participants to outlook the overall plan of the project. Understanding the interdependencies of the actions and their relationships has a direct link with the improvement of work efficiency, collaboration, and distribution of efforts (Aibinu \& Papadonikolaki, 2020).

Considering that one of the great difficulties of BIM implementation is the insufficiency of skilled labor, having a clear and concise methodology is a positive and determinant point for effective implementation. As a result, the processes could be appropriately designed and detailed, counting on the team's participation and collaboration as an essential factor for the development of the project.

Participants interacted in the design of the processes by adding activities and requirements, thus adding value to the BIMIP. This planning strategy directed the team to understand and assimilate the adaptation needs to the new processes. This point confirms that the view that collaborative work is the drive for BIM implementation, and therefore the transformation agent includes many actors and not just a customer's vision (Lindblad, 2019).

The inclusion of formal and informal activities was an evident point of the project's overall mapping since, with the division of scope, all the efforts necessary to execute the product are visible, relationships already described before by the literature (Papadonikolaki et al., 2017)

The lack of rules or parameters were detected in this experience and also in the related literature. The approach depends on the environment, the experience of the participants, and the company's maturity. Therefore, a proposal aimed at uniting the company's culture with the new BIM processes is beneficial for the dissemination of this methodology. 


\section{$6^{\text {th }}$ International Conference On}

Modern Approaches in SCIENCE, TECHNOLOGY \& ENGINEERING

\section{8 - 20 September, 2020 MILAN, ITALY}

In this sense, the customization of the BIM implementation is an essential factor to be planned, following the existing techniques, know-how and, mainly, with the focus on objectives aligned with the real needs of the client, obviously the most interested in a positive result of the investment made in the methodology.

Figure 11-BIM Structured Implementation Method

\begin{tabular}{|c|c|c|c|c|c|}
\hline \multicolumn{6}{|c|}{ BIM WORKING AREAS } \\
\hline Process & Information & Strategy & Infrastructure & Uses & People \\
\hline \multicolumn{6}{|l|}{ ALIGNMENT } \\
\hline \multicolumn{6}{|c|}{ Priority definitions according to the organization's requirements } \\
\hline \begin{tabular}{|c|} 
New processes for new \\
uses; Iransition from the \\
old to the new one
\end{tabular} & $\begin{array}{l}\text { Project needs and } \\
\text { requirements useful } \\
\text { level of detail }\end{array}$ & $\begin{array}{l}\text { Goals and objectives; } \\
\text { Available supports and } \\
\text { resources }\end{array}$ & $\begin{array}{l}\text { Software, hardware, } \\
\text { network, physical space } \\
\text { that the organization } \\
\text { needs }\end{array}$ & $\begin{array}{l}\text { Uses of the model to } \\
\text { generate, precess, } \\
\text { communicate, execute } \\
\text { and manage }\end{array}$ & $\begin{array}{l}\text { Rules, responsibilities, } \\
\text { training, new BIM team }\end{array}$ \\
\hline
\end{tabular}

\begin{tabular}{|c|c|c|c|}
\hline \multicolumn{4}{|c|}{ Activities required to execute the model } \\
\hline phases & & Project phases & \\
\hline 3 至 & Project planing & Model design & Collaborative Model \\
\hline Diagnostic & $\begin{array}{l}\text { Team definition, organization chart, } \\
\text { current processes, information flow, team } \\
\text { activities }\end{array}$ & $\begin{array}{l}\text { Distribute project status report, } \\
\text { requirements to respond to BoQ, check } \\
\text { current project }\end{array}$ & $\begin{array}{l}\text { Verify the status of the project presented, } \\
\text { verify compatibility }\end{array}$ \\
\hline Training & Conceptual BIM for management & Revit and Navisworks for colaboration & $\begin{array}{l}\text { Infraworks and collaboration for } \\
\text { CCSCandy }\end{array}$ \\
\hline $\begin{array}{l}\text { System } \\
\text { Integration }\end{array}$ & $\begin{array}{l}\text { Definition of the collaboration platform } \\
\text { (website, company network), definition of } \\
\text { software }\end{array}$ & $\begin{array}{l}\text { Distribution of information and } \\
\text { documents produced that should be } \\
\text { followed }\end{array}$ & $\begin{array}{l}\text { Perform activities on a collaborative } \\
\text { platform, verify compliance with defined } \\
\text { standards, update documents }\end{array}$ \\
\hline PEB & $\begin{array}{l}\text { Formatting and structure of drawings - } \\
\text { nomenclatures, flow of deliveries, } \\
\text { registration of information requirements }\end{array}$ & Update of PEB with model information & Update of PEB with model information \\
\hline Procurement & $\begin{array}{l}\text { Requirements for designer's contracts and } \\
\text { evaluation model, capacity measurement } \\
\text { form }\end{array}$ & Define consultants and designers & $\begin{array}{l}\text { Manage designer contracts (schedules and } \\
\text { payments) }\end{array}$ \\
\hline Process & $\begin{array}{l}\text { Indexes, classification systems, modeling } \\
\text { rules }\end{array}$ & $\begin{array}{l}\text { Verifitfy the indexes, design the project } \\
\text { process with verified inputs }\end{array}$ & $\begin{array}{l}\text { Update processes, include collaboration, } \\
\text { new inputs, ensure information transfer }\end{array}$ \\
\hline Schedule & $\begin{array}{l}\text { Create modeling schedule, projects in } \\
\text { different stages of design maturity }\end{array}$ & $\begin{array}{l}\text { Manage the schedule through the } \\
\text { collaborative platform, update status }\end{array}$ & $\begin{array}{l}\text { Manage the schedule through the } \\
\text { collaborative platform, update status }\end{array}$ \\
\hline Modeling & $\begin{array}{l}\text { Verification of the existing basic } \\
\text { information, organization of the } \\
\text { information to be modeled, LOD, LOI }\end{array}$ & $\begin{array}{l}\text { Modeling -parameterizing the information } \\
\text { following the } \mathrm{BoQ}\end{array}$ & $\begin{array}{l}\text { Model analysis, verification of added } \\
\text { information preparing the collaborative } \\
\text { model for Navisworks and Infraworks }\end{array}$ \\
\hline $\begin{array}{l}\text { Document } \\
\text { Management }\end{array}$ & $\begin{array}{l}\text { Documentation of Request for } \\
\text { Information }\end{array}$ & $\begin{array}{l}\text { Manage published files, model quality } \\
\text { control }\end{array}$ & $\begin{array}{l}\text { Manage clash detection and phase } \\
\text { documentationx }\end{array}$ \\
\hline Meetings & $\begin{array}{l}\text { Define distribution platform, define } \\
\text { responsible, define template }\end{array}$ & $\begin{array}{l}\text { Run project meetings, record and approve } \\
\text { project meetings }\end{array}$ & $\begin{array}{l}\text { Run project meetings, record and approve } \\
\text { project meetings }\end{array}$ \\
\hline
\end{tabular}




\section{References}

AEC (UK). (2012). AEC (UK) BIM Protocol Implementing UK BIM Standards for the Architectural, Engineering and Construction industry. https://aecuk.files.wordpress.com/2012/09/aecukbimprotocol-v2-0.pdf

Ahmad, M., Ahmad, A., Demian, P., \& Price, A. (2012). BIM implementation plans: A comparative analysis (Vol. 1).

Aibinu, A. A., \& Papadonikolaki, E. (2020). Conceptualizing and operationalizing team task interdependences: BIM implementation assessment using effort distribution analytics. Construction Management and Economics. https://doi.org/10.1080/01446193.2019.1623409

Arayici, Y., Egbu, C., \& Coates, S. (2012). Building information modelling (BIM) implementation and remote construction projects: issues, challenges, and critiques. In Electronic Journal of Information Technology in Construction (Vol. 17).

Azhar, S. (2011). Building Information Modeling (BIM): Trends, Benefits, Risks, and Challenges for the AEC Industry. In Leadership and Management in Engineering (Vol. 11). https://doi.org/10.1061/(ASCE)LM.1943-5630.0000127

Azzouz, A., \& Hill, P. (2017). How BIM is assessed using Arup's BIM maturity measure? Association of Researchers in Construction Management, ARCOM - 33rd Annual Conference 2017, Proceeding.

BCA - Building and Construction Authority. (2013). Singapore BIM Guide - V2.0. Corenet.

BSI. (2013). PAS 1192-2:2013 Specification for information management for the capital/delivery phase of construction projects using building information modelling. BSI Standards Publication. https://doi.org/Published by the British Standard Institute. British Standard Limited. ISSN9780580781360. /BIM TASK GROUP

Chae, L. S., \& Kang, J. (2015). Understanding of Essential BIM Skills through BIM Guidelines. 51st ASC Annual International Conference.

Coates, P., Arayici, Y., Koskela, L., Kagioglou, M., Usher, C., \& O’Reilly, K. (2010). The key performance indicators of the BIM implementation process. EG-ICE 2010 - 17th International Workshop on Intelligent Computing in Engineering.

Digital Infrastructure, F. M. of T. and. (2015). Road Map for Digital Design and Construction.Introduction of modern, IT-based processes and technologies for the design, construction and operation of assets in the built environment.

Eastman, C. (2011). BIM Handbook Introduction. In BIM Handbook, A guide to building information modelling for owners, managers, designers, engineers, and contractors.

Eastman, C., Teicholz, P., Sacks, R., \& Liston, K. (2011). BIM Handbook: A Guide to Building Information Modeling For Owners. In Managers, Architects, Engineers and 


\section{8 - 20 September, 2020 MILAN, ITALY}

\section{Contractors.}

EUBIM Task Group. (2016). Handbook for the introduction of Building Information Modelling by the European Public Sector. In EUBIM Task Group.

Howard, R., \& Björk, B. C. (2008). Building information modelling - Experts' views on standardisation and industry deployment. Advanced Engineering Informatics. https://doi.org/10.1016/j.aei.2007.03.001

International Organization for Standardization (ISO). (2017). ISO/DIS 19650-1 - Part 1: Concepts and Principles. ISO 2017.

Kassem, M., Succar, B., \& Dawood, N. (2013). A proposed approach to comparing the BIM maturity of countries| NOVA. The University of Newcastle's Digital Repository. Proceedings of the CIB W78 2013: 30th International Conference. http://novaprdlb.newcastle.edu.au/vital/access/manager/Repository/uon:15200

Lindblad, H. (2019). Black boxing BIM: the public client's strategy in BIM implementation. Construction Management and Economics. https://doi.org/10.1080/01446193.2018.1472385

Mahamadu, A.-M., Navendren, D., Manu, P., Joseph, R., \& Dziekonski, K. (2017). Addressing challenges to building information modelling implementation in UK: designers' perspectives. Journal of Construction Project Management and Innovation. https://doi.org/https://hdl.handle.net/10520/EJC-af2d94e0b

McGraw Hill Construction. (2014). The business value of BIM for construction in major global markets. In SmartMarket Report.

Migilinskas, D., Popov, V., Juocevicius, V., \& Ustinovichius, L. (2013). The benefits, obstacles and problems of practical bim implementation. Procedia Engineering. https://doi.org/10.1016/j.proeng.2013.04.097

Navendren, D., Manu, P., Shelbourn, M., \& Mahamadu, A.-M. (2014). Challenges to building information modelling implementation in UK: Designers' perspectives. https://www.scopus.com/inward/record.uri?eid=2-s2.0-

84911429580\&partnerID=40\&md5=81ba8f427f53f8b1b634ff $888664 a 7 a c$

NBS. (2019). National BIM Report 2019. In National BIM Report 2019 The definitive industry update. https://doi.org/10.1017/CBO9781107415324.004

Observatory, E. construction sector. (2019). Building Information Modelling in the UK construction sector.

Papadonikolaki, E., Verbraeck, A., \& Wamelink, H. (2017). Formal and informal relations within BIM-enabled supply chain partnerships. https://doi.org/10.1080/01446193.2017.1311020

PMI. (2013). Project management body of knowledge (pmbok® guide).

Pruskova, K., \& Kaiser, J. (2019). Implementation of BIM Technology into the Design Process Using the Scheme of BIM Execution Plan. IOP Conference Series: Materials Science and Engineering. https://doi.org/10.1088/1757-899X/471/2/022019

Rogers, E. M. (2003). Diffusion of Innovations, Fifth Edition. In Social Networks. 
Shou, W., Wang, J., Wang, X., \& Chong, H. Y. (2015). A Comparative Review of Building Information Modelling Implementation in Building and Infrastructure Industries. Archives of Computational Methods in Engineering. https://doi.org/10.1007/s11831-014-9125-9

Silva, M. J. F., Salvado, F., Couto, P., \& Azevedo, Á. V. e. (2016). Roadmap Proposal for Implementing Building Information Modelling (BIM) in Portugal. Open Journal of Civil Engineering. https://doi.org/10.4236/ojce.2016.63040

Smith, P. (2014). BIM Implementation - Global Strategies. Procedia Engineering, 85, 482492. https://doi.org/https://doi.org/10.1016/j.proeng.2014.10.575

State, P. (2010). BIM Project Execution Planning Guide - Version 2.0. Computer Integrated Construction Research Program. https://www.bim.psu.edu/

Succar, B. (2009). Building information modelling framework: A research and delivery foundation for industry stakeholders. Automation in Construction. https://doi.org/10.1016/j.autcon.2008.10.003

Succar, B. (2010). The Five Components of BIM Performance Measurement. CIB World Congress, Salford, United Kingdom.

The Pennsylvania State University. (2013). BIM Planning Guide for Facility Owners. http://bim.psu.edu

Wu, W, Mayo, G., McCuen, T. L., Issa, R. R. A., \& Smith, D. K. (2018a). Building Information Modeling Body of Knowledge. I: Background, Framework, and Initial Development. https://doi.org/10.1061/(ASCE)CO.1943-7862.0001518

Wu, W, Mayo, G., McCuen, T. L., Issa, R. R. A., \& Smith, D. K. (2018b). Building Information Modeling Body of Knowledge. II: Consensus Building and Use Cases. https://doi.org/10.1061/(ASCE)CO.1943-7862.0001536

$\mathrm{Wu}$, Wei, \& Issa, R. R. A. (2014). Key issues in workforce planning and adaptation strategies for BIM implementation in construction industry. Construction Research Congress 2014: Construction in a Global Network - Proceedings of the 2014 Construction Research Congress. https://doi.org/10.1061/9780784413517.0087

Zhang, J., Schmidt, K., \& Li, H. (2016). BIM and sustainability education: Incorporating instructional needs into curriculum planning in CEM programs accredited by ACCE. Sustainability (Switzerland), 8(6). https://doi.org/10.3390/su8060525

AEC (UK). (2012). AEC (UK) BIM Protocol Implementing UK BIM Standards for the Architectural, Engineering and Construction industry. https://aecuk.files.wordpress.com/2012/09/aecukbimprotocol-v2-0.pdf

Ahmad, M., Ahmad, A., Demian, P., \& Price, A. (2012). BIM implementation plans: A comparative analysis (Vol. 1).

Aibinu, A. A., \& Papadonikolaki, E. (2020). Conceptualizing and operationalizing team task interdependences: BIM implementation assessment using effort distribution analytics. Construction Management and Economics. https://doi.org/10.1080/01446193.2019.1623409

Arayici, Y., Egbu, C., \& Coates, S. (2012). Building information modelling (BIM) 
implementation and remote construction projects: issues, challenges, and critiques. In Electronic Journal of Information Technology in Construction (Vol. 17).

Azhar, S. (2011). Building Information Modeling (BIM): Trends, Benefits, Risks, and Challenges for the AEC Industry. In Leadership and Management in Engineering (Vol.

11). https://doi.org/10.1061/(ASCE)LM.1943-5630.0000127

Azzouz, A., \& Hill, P. (2017). How BIM is assessed using Arup's BIM maturity measure? Association of Researchers in Construction Management, ARCOM - 33rd Annual Conference 2017, Proceeding.

BCA - Building and Construction Authority. (2013). Singapore BIM Guide - V2.0. Corenet.

BSI. (2013). PAS 1192-2:2013 Specification for information management for the capital/delivery phase of construction projects using building information modelling. BSI Standards Publication. https://doi.org/Published by the British Standard Institute. British Standard Limited. ISSN9780580781360. /BIM TASK GROUP

Chae, L. S., \& Kang, J. (2015). Understanding of Essential BIM Skills through BIM Guidelines. 51st ASC Annual International Conference.

Coates, P., Arayici, Y., Koskela, L., Kagioglou, M., Usher, C., \& O’Reilly, K. (2010). The key performance indicators of the BIM implementation process. EG-ICE 2010 - 17th International Workshop on Intelligent Computing in Engineering.

Digital Infrastructure, F. M. of T. and. (2015). Road Map for Digital Design and Construction.Introduction of modern, IT-based processes and technologies for the design, construction and operation of assets in the built environment.

Eastman, C. (2011). BIM Handbook Introduction. In BIM Handbook, A guide to building information modelling for owners, managers, designers, engineers, and contractors.

Eastman, C., Teicholz, P., Sacks, R., \& Liston, K. (2011). BIM Handbook: A Guide to Building Information Modeling For Owners. In Managers, Architects, Engineers and Contractors.

EUBIM Task Group. (2016). Handbook for the introduction of Building Information Modelling by the European Public Sector. In EUBIM Task Group.

Howard, R., \& Björk, B. C. (2008). Building information modelling - Experts' views on standardisation and industry deployment. Advanced Engineering Informatics. https://doi.org/10.1016/j.aei.2007.03.001

International Organization for Standardization (ISO). (2017). ISO/DIS 19650-1 - Part 1: Concepts and Principles. ISO 2017.

Kassem, M., Succar, B., \& Dawood, N. (2013). A proposed approach to comparing the BIM maturity of countries $\mid$ NOVA. The University of Newcastle's Digital Repository. Proceedings of the CIB W78 2013: 30th International Conference. http://novaprdlb.newcastle.edu.au/vital/access/manager/Repository/uon:15200

Lindblad, H. (2019). Black boxing BIM: the public client's strategy in BIM implementation. Construction $\quad$ Management
https://doi.org/10.1080/01446193.2018.1472385 
Mahamadu, A.-M., Navendren, D., Manu, P., Joseph, R., \& Dziekonski, K. (2017). Addressing challenges to building information modelling implementation in UK: designers' perspectives. Journal of Construction Project Management and Innovation. https://doi.org/https://hdl.handle.net/10520/EJC-af2d94e0b

McGraw Hill Construction. (2014). The business value of BIM for construction in major global markets. In SmartMarket Report.

Migilinskas, D., Popov, V., Juocevicius, V., \& Ustinovichius, L. (2013). The benefits, obstacles and problems of practical bim implementation. Procedia Engineering. https://doi.org/10.1016/j.proeng.2013.04.097

Navendren, D., Manu, P., Shelbourn, M., \& Mahamadu, A.-M. (2014). Challenges to building information modelling implementation in UK: Designers' perspectives. https://www.scopus.com/inward/record.uri?eid=2-s2.0-

84911429580\&partnerID=40\&md5=81ba8f427f53f8b1b634ff888664a7ac

NBS. (2019). National BIM Report 2019. In National BIM Report 2019 The definitive industry update. https://doi.org/10.1017/CBO9781107415324.004

Observatory, E. construction sector. (2019). Building Information Modelling in the UK construction sector.

Papadonikolaki, E., Verbraeck, A., \& Wamelink, H. (2017). Formal and informal relations within BIM-enabled supply chain partnerships. https://doi.org/10.1080/01446193.2017.1311020

PMI. (2013). Project management body of knowledge (pmbok® guide).

Pruskova, K., \& Kaiser, J. (2019). Implementation of BIM Technology into the Design Process Using the Scheme of BIM Execution Plan. IOP Conference Series: Materials Science and Engineering. https://doi.org/10.1088/1757-899X/471/2/022019

Rogers, E. M. (2003). Diffusion of Innovations, Fifth Edition. In Social Networks.

Shou, W., Wang, J., Wang, X., \& Chong, H. Y. (2015). A Comparative Review of Building Information Modelling Implementation in Building and Infrastructure Industries. Archives of Computational Methods in Engineering. https://doi.org/10.1007/s11831-014-9125-9

Silva, M. J. F., Salvado, F., Couto, P., \& Azevedo, Á. V. e. (2016). Roadmap Proposal for Implementing Building Information Modelling (BIM) in Portugal. Open Journal of Civil Engineering. https://doi.org/10.4236/ojce.2016.63040

Smith, P. (2014). BIM Implementation - Global Strategies. Procedia Engineering, 85, 482492. https://doi.org/https://doi.org/10.1016/j.proeng.2014.10.575

State, P. (2010). BIM Project Execution Planning Guide - Version 2.0. Computer Integrated Construction Research Program. https://www.bim.psu.edu/

Succar, B. (2009). Building information modelling framework: A research and delivery foundation for industry stakeholders. Automation in Construction. https://doi.org/10.1016/j.autcon.2008.10.003

Succar, B. (2010). The Five Components of BIM Performance Measurement. CIB World Congress, Salford, United Kingdom. 


\section{8 - 20 September, 2020 MILAN, ITALY}

The Pennsylvania State University. (2013). BIM Planning Guide for Facility Owners. http://bim.psu.edu

Wu, W, Mayo, G., McCuen, T. L., Issa, R. R. A., \& Smith, D. K. (2018a). Building Information Modeling Body of Knowledge. I: Background, Framework, and Initial Development. https://doi.org/10.1061/(ASCE)CO.1943-7862.0001518

Wu, W, Mayo, G., McCuen, T. L., Issa, R. R. A., \& Smith, D. K. (2018b). Building Information Modeling Body of Knowledge. II: Consensus Building and Use Cases. https://doi.org/10.1061/(ASCE)CO.1943-7862.0001536

Wu, Wei, \& Issa, R. R. A. (2014). Key issues in workforce planning and adaptation strategies for BIM implementation in construction industry. Construction Research Congress 2014: Construction in a Global Network - Proceedings of the 2014 Construction Research Congress. https://doi.org/10.1061/9780784413517.0087

Zhang, J., Schmidt, K., \& Li, H. (2016). BIM and sustainability education: Incorporating instructional needs into curriculum planning in CEM programs accredited by ACCE. Sustainability (Switzerland), 8(6). https://doi.org/10.3390/su8060525

AEC (UK). (2012). AEC (UK) BIM Protocol Implementing UK BIM Standards for the Architectural, Engineering and Construction industry. https://aecuk.files.wordpress.com/2012/09/aecukbimprotocol-v2-0.pdf

Ahmad, M., Ahmad, A., Demian, P., \& Price, A. (2012). BIM implementation plans: A comparative analysis (Vol. 1).

Aibinu, A. A., \& Papadonikolaki, E. (2020). Conceptualizing and operationalizing team task interdependences: BIM implementation assessment using effort distribution analytics. Construction Management and Economics. https://doi.org/10.1080/01446193.2019.1623409

Arayici, Y., Egbu, C., \& Coates, S. (2012). Building information modelling (BIM) implementation and remote construction projects: issues, challenges, and critiques. In Electronic Journal of Information Technology in Construction (Vol. 17).

Azhar, S. (2011). Building Information Modeling (BIM): Trends, Benefits, Risks, and Challenges for the AEC Industry. In Leadership and Management in Engineering (Vol. 11). https://doi.org/10.1061/(ASCE)LM.1943-5630.0000127

Azzouz, A., \& Hill, P. (2017). How BIM is assessed using Arup's BIM maturity measure? Association of Researchers in Construction Management, ARCOM - 33rd Annual Conference 2017, Proceeding.

BCA - Building and Construction Authority. (2013). Singapore BIM Guide - V2.0. Corenet.

BSI. (2013). PAS 1192-2:2013 Specification for information management for the capital/delivery phase of construction projects using building information modelling. BSI Standards Publication. https://doi.org/Published by the British Standard Institute. British Standard Limited. ISSN9780580781360. /BIM TASK GROUP

Chae, L. S., \& Kang, J. (2015). Understanding of Essential BIM Skills through BIM Guidelines. 51 st ASC Annual International Conference. 


\section{8 - 20 September, 2020 MILAN, ITALY}

Coates, P., Arayici, Y., Koskela, L., Kagioglou, M., Usher, C., \& O’Reilly, K. (2010). The key performance indicators of the BIM implementation process. EG-ICE 2010 - 17th International Workshop on Intelligent Computing in Engineering .

Digital Infrastructure, F. M. of T. and. (2015). Road Map for Digital Design and Construction.Introduction of modern, IT-based processes and technologies for the design, construction and operation of assets in the built environment.

Eastman, C. (2011). BIM Handbook Introduction. In BIM Handbook, A guide to building information modelling for owners, managers, designers, engineers, and contractors.

Eastman, C., Teicholz, P., Sacks, R., \& Liston, K. (2011). BIM Handbook: A Guide to Building Information Modeling For Owners. In Managers, Architects, Engineers and Contractors.

EUBIM Task Group. (2016). Handbook for the introduction of Building Information Modelling by the European Public Sector. In EUBIM Task Group.

Howard, R., \& Björk, B. C. (2008). Building information modelling - Experts' views on standardisation and industry deployment. Advanced Engineering Informatics. https://doi.org/10.1016/j.aei.2007.03.001

International Organization for Standardization (ISO). (2017). ISO/DIS 19650-1 - Part 1: Concepts and Principles. ISO 2017.

Kassem, M., Succar, B., \& Dawood, N. (2013). A proposed approach to comparing the BIM maturity of countries| NOVA. The University of Newcastle's Digital Repository. Proceedings of the CIB W78 2013: 30th International Conference. http://novaprdlb.newcastle.edu.au/vital/access/manager/Repository/uon:15200

Lindblad, H. (2019). Black boxing BIM: the public client's strategy in BIM implementation. Construction Management and Economics. https://doi.org/10.1080/01446193.2018.1472385

Mahamadu, A.-M., Navendren, D., Manu, P., Joseph, R., \& Dziekonski, K. (2017). Addressing challenges to building information modelling implementation in UK: designers' perspectives. Journal of Construction Project Management and Innovation. https://doi.org/https://hdl.handle.net/10520/EJC-af2d94e0b

McGraw Hill Construction. (2014). The business value of BIM for construction in major global markets. In SmartMarket Report.

Migilinskas, D., Popov, V., Juocevicius, V., \& Ustinovichius, L. (2013). The benefits, obstacles and problems of practical bim implementation. Procedia Engineering. https://doi.org/10.1016/j.proeng.2013.04.097

Navendren, D., Manu, P., Shelbourn, M., \& Mahamadu, A.-M. (2014). Challenges to building information modelling implementation in UK: Designers' perspectives. https://www.scopus.com/inward/record.uri?eid=2-s2.0-

84911429580\&partnerID=40\&md5=81ba8f427f53f8b1b634ff $888664 a 7 a c$

NBS. (2019). National BIM Report 2019. In National BIM Report 2019 The definitive industry update. https://doi.org/10.1017/CBO9781107415324.004 


\section{8 - 20 September, 2020 MILAN, ITALY}

Observatory, E. construction sector. (2019). Building Information Modelling in the UK construction sector.

Papadonikolaki, E., Verbraeck, A., \& Wamelink, H. (2017). Formal and informal relations within BIM-enabled supply chain partnerships. https://doi.org/10.1080/01446193.2017.1311020

PMI. (2013). Project management body of knowledge (pmbok® guide).

Pruskova, K., \& Kaiser, J. (2019). Implementation of BIM Technology into the Design Process Using the Scheme of BIM Execution Plan. IOP Conference Series: Materials Science and Engineering. https://doi.org/10.1088/1757-899X/471/2/022019

Rogers, E. M. (2003). Diffusion of Innovations, Fifth Edition. In Social Networks.

Shou, W., Wang, J., Wang, X., \& Chong, H. Y. (2015). A Comparative Review of Building Information Modelling Implementation in Building and Infrastructure Industries. Archives of Computational Methods in Engineering. https://doi.org/10.1007/s11831-014-9125-9

Silva, M. J. F., Salvado, F., Couto, P., \& Azevedo, Á. V. e. (2016). Roadmap Proposal for Implementing Building Information Modelling (BIM) in Portugal. Open Journal of Civil Engineering. https://doi.org/10.4236/ojce.2016.63040

Smith, P. (2014). BIM Implementation - Global Strategies. Procedia Engineering, 85, 482492. https://doi.org/https://doi.org/10.1016/j.proeng.2014.10.575

State, P. (2010). BIM Project Execution Planning Guide - Version 2.0. Computer Integrated Construction Research Program. https://www.bim.psu.edu/

Succar, B. (2009). Building information modelling framework: A research and delivery foundation for industry stakeholders. Automation in Construction. https://doi.org/10.1016/j.autcon.2008.10.003

Succar, B. (2010). The Five Components of BIM Performance Measurement. CIB World Congress, Salford, United Kingdom.

The Pennsylvania State University. (2013). BIM Planning Guide for Facility Owners. http://bim.psu.edu

Wu, W, Mayo, G., McCuen, T. L., Issa, R. R. A., \& Smith, D. K. (2018a). Building Information Modeling Body of Knowledge. I: Background, Framework, and Initial Development. https://doi.org/10.1061/(ASCE)CO.1943-7862.0001518

Wu, W, Mayo, G., McCuen, T. L., Issa, R. R. A., \& Smith, D. K. (2018b). Building Information Modeling Body of Knowledge. II: Consensus Building and Use Cases. https://doi.org/10.1061/(ASCE)CO.1943-7862.0001536

Wu, Wei, \& Issa, R. R. A. (2014). Key issues in workforce planning and adaptation strategies for BIM implementation in construction industry. Construction Research Congress 2014: Construction in a Global Network - Proceedings of the 2014 Construction Research Congress. https://doi.org/10.1061/9780784413517.0087

Zhang, J., Schmidt, K., \& Li, H. (2016). BIM and sustainability education: Incorporating instructional needs into curriculum planning in CEM programs accredited by ACCE. Sustainability (Switzerland), 8(6). https://doi.org/10.3390/su8060525 


\section{8 - 20 September, 2020 MILAN, ITALY}

AEC (UK). (2012). AEC (UK) BIM Protocol Implementing UK BIM Standards for the Architectural, Engineering and Construction industry. https://aecuk.files.wordpress.com/2012/09/aecukbimprotocol-v2-0.pdf

Ahmad, M., Ahmad, A., Demian, P., \& Price, A. (2012). BIM implementation plans: A comparative analysis (Vol. 1).

Aibinu, A. A., \& Papadonikolaki, E. (2020). Conceptualizing and operationalizing team task interdependences: BIM implementation assessment using effort distribution analytics. Construction Management and Economics. https://doi.org/10.1080/01446193.2019.1623409

Arayici, Y., Egbu, C., \& Coates, S. (2012). Building information modelling (BIM) implementation and remote construction projects: issues, challenges, and critiques. In Electronic Journal of Information Technology in Construction (Vol. 17).

Azhar, S. (2011). Building Information Modeling (BIM): Trends, Benefits, Risks, and Challenges for the AEC Industry. In Leadership and Management in Engineering (Vol. 11). https://doi.org/10.1061/(ASCE)LM.1943-5630.0000127

Azzouz, A., \& Hill, P. (2017). How BIM is assessed using Arup's BIM maturity measure? Association of Researchers in Construction Management, ARCOM - 33rd Annual Conference 2017, Proceeding.

BCA - Building and Construction Authority. (2013). Singapore BIM Guide - V2.0. Corenet.

BSI. (2013). PAS 1192-2:2013 Specification for information management for the capital/delivery phase of construction projects using building information modelling. BSI Standards Publication. https://doi.org/Published by the British Standard Institute. British Standard Limited. ISSN9780580781360. /BIM TASK GROUP

Chae, L. S., \& Kang, J. (2015). Understanding of Essential BIM Skills through BIM Guidelines. 51 st ASC Annual International Conference.

Coates, P., Arayici, Y., Koskela, L., Kagioglou, M., Usher, C., \& O’Reilly, K. (2010). The key performance indicators of the BIM implementation process. EG-ICE 2010 - 17th International Workshop on Intelligent Computing in Engineering.

Digital Infrastructure, F. M. of T. and. (2015). Road Map for Digital Design and Construction.Introduction of modern, IT-based processes and technologies for the design, construction and operation of assets in the built environment.

Eastman, C. (2011). BIM Handbook Introduction. In BIM Handbook, A guide to building information modelling for owners, managers, designers, engineers, and contractors.

Eastman, C., Teicholz, P., Sacks, R., \& Liston, K. (2011). BIM Handbook: A Guide to Building Information Modeling For Owners. In Managers, Architects, Engineers and Contractors.

EUBIM Task Group. (2016). Handbook for the introduction of Building Information Modelling by the European Public Sector. In EUBIM Task Group.

Howard, R., \& Björk, B. C. (2008). Building information modelling - Experts' views on standardisation and industry deployment. Advanced Engineering Informatics. 
https://doi.org/10.1016/j.aei.2007.03.001

International Organization for Standardization (ISO). (2017). ISO/DIS 19650-1 - Part 1: Concepts and Principles. ISO 2017.

Kassem, M., Succar, B., \& Dawood, N. (2013). A proposed approach to comparing the BIM maturity of countries| NOVA. The University of Newcastle's Digital Repository. Proceedings of the CIB W78 2013: 30th International Conference. http://novaprdlb.newcastle.edu.au/vital/access/manager/Repository/uon:15200

Lindblad, H. (2019). Black boxing BIM: the public client's strategy in BIM implementation. Construction Management and Economics. https://doi.org/10.1080/01446193.2018.1472385

Mahamadu, A.-M., Navendren, D., Manu, P., Joseph, R., \& Dziekonski, K. (2017). Addressing challenges to building information modelling implementation in UK: designers' perspectives. Journal of Construction Project Management and Innovation. https://doi.org/https://hdl.handle.net/10520/EJC-af2d94e0b

McGraw Hill Construction. (2014). The business value of BIM for construction in major global markets. In SmartMarket Report.

Migilinskas, D., Popov, V., Juocevicius, V., \& Ustinovichius, L. (2013). The benefits, obstacles and problems of practical bim implementation. Procedia Engineering. https://doi.org/10.1016/j.proeng.2013.04.097

Navendren, D., Manu, P., Shelbourn, M., \& Mahamadu, A.-M. (2014). Challenges to building information modelling implementation in UK: Designers' perspectives. https://www.scopus.com/inward/record.uri?eid=2-s2.0-

84911429580\&partnerID=40\&md5=81ba8f427f53f8b1b634ff888664a7ac

NBS. (2019). National BIM Report 2019. In National BIM Report 2019 The definitive industry update. https://doi.org/10.1017/CBO9781107415324.004

Observatory, E. construction sector. (2019). Building Information Modelling in the UK construction sector.

Papadonikolaki, E., Verbraeck, A., \& Wamelink, H. (2017). Formal and informal relations within BIM-enabled supply chain partnerships. https://doi.org/10.1080/01446193.2017.1311020

PMI. (2013). Project management body of knowledge (pmbok® guide).

Pruskova, K., \& Kaiser, J. (2019). Implementation of BIM Technology into the Design Process Using the Scheme of BIM Execution Plan. IOP Conference Series: Materials Science and Engineering. https://doi.org/10.1088/1757-899X/471/2/022019

Rogers, E. M. (2003). Diffusion of Innovations, Fifth Edition. In Social Networks.

Shou, W., Wang, J., Wang, X., \& Chong, H. Y. (2015). A Comparative Review of Building Information Modelling Implementation in Building and Infrastructure Industries. Archives of Computational Methods in Engineering. https://doi.org/10.1007/s11831-014-9125-9

Silva, M. J. F., Salvado, F., Couto, P., \& Azevedo, Á. V. e. (2016). Roadmap Proposal for Implementing Building Information Modelling (BIM) in Portugal. Open Journal of Civil 


\section{8 - 20 September, 2020 MILAN, ITALY}

Engineering. https://doi.org/10.4236/ojce.2016.63040

Smith, P. (2014). BIM Implementation - Global Strategies. Procedia Engineering, 85, 482492. https://doi.org/https://doi.org/10.1016/j.proeng.2014.10.575

State, P. (2010). BIM Project Execution Planning Guide - Version 2.0. Computer Integrated Construction Research Program. https://www.bim.psu.edu/

Succar, B. (2009). Building information modelling framework: A research and delivery foundation for industry stakeholders. Automation in Construction. https://doi.org/10.1016/j.autcon.2008.10.003

Succar, B. (2010). The Five Components of BIM Performance Measurement. CIB World Congress, Salford, United Kingdom.

The Pennsylvania State University. (2013). BIM Planning Guide for Facility Owners. http://bim.psu.edu

Wu, W, Mayo, G., McCuen, T. L., Issa, R. R. A., \& Smith, D. K. (2018a). Building Information Modeling Body of Knowledge. I: Background, Framework, and Initial Development. https://doi.org/10.1061/(ASCE)CO.1943-7862.0001518

Wu, W, Mayo, G., McCuen, T. L., Issa, R. R. A., \& Smith, D. K. (2018b). Building Information Modeling Body of Knowledge. II: Consensus Building and Use Cases. https://doi.org/10.1061/(ASCE)CO.1943-7862.0001536

$\mathrm{Wu}$, Wei, \& Issa, R. R. A. (2014). Key issues in workforce planning and adaptation strategies for BIM implementation in construction industry. Construction Research Congress 2014: Construction in a Global Network - Proceedings of the 2014 Construction Research Congress. https://doi.org/10.1061/9780784413517.0087

Zhang, J., Schmidt, K., \& Li, H. (2016). BIM and sustainability education: Incorporating instructional needs into curriculum planning in CEM programs accredited by ACCE. Sustainability (Switzerland), 8(6). https://doi.org/10.3390/su8060525

AEC (UK). (2012). AEC (UK) BIM Protocol Implementing UK BIM Standards for the Architectural, Engineering and Construction industry. https://aecuk.files.wordpress.com/2012/09/aecukbimprotocol-v2-0.pdf

Ahmad, M., Ahmad, A., Demian, P., \& Price, A. (2012). BIM implementation plans: A comparative analysis (Vol. 1).

Aibinu, A. A., \& Papadonikolaki, E. (2020). Conceptualizing and operationalizing team task interdependences: BIM implementation assessment using effort distribution analytics. Construction Management and Economics. https://doi.org/10.1080/01446193.2019.1623409

Arayici, Y., Egbu, C., \& Coates, S. (2012). Building information modelling (BIM) implementation and remote construction projects: issues, challenges, and critiques. In Electronic Journal of Information Technology in Construction (Vol. 17).

Azhar, S. (2011). Building Information Modeling (BIM): Trends, Benefits, Risks, and Challenges for the AEC Industry. In Leadership and Management in Engineering (Vol. 11). https://doi.org/10.1061/(ASCE)LM.1943-5630.0000127 


\section{8 - 20 September, 2020 MILAN, ITALY}

Azzouz, A., \& Hill, P. (2017). How BIM is assessed using Arup's BIM maturity measure? Association of Researchers in Construction Management, ARCOM - 33rd Annual Conference 2017, Proceeding.

BCA - Building and Construction Authority. (2013). Singapore BIM Guide - V2.0. Corenet.

BSI. (2013). PAS 1192-2:2013 Specification for information management for the capital/delivery phase of construction projects using building information modelling. BSI Standards Publication. https://doi.org/Published by the British Standard Institute. British Standard Limited. ISSN9780580781360. /BIM TASK GROUP

Chae, L. S., \& Kang, J. (2015). Understanding of Essential BIM Skills through BIM Guidelines. 51 st ASC Annual International Conference.

Coates, P., Arayici, Y., Koskela, L., Kagioglou, M., Usher, C., \& O’Reilly, K. (2010). The key performance indicators of the BIM implementation process. EG-ICE $2010-17$ th International Workshop on Intelligent Computing in Engineering.

Digital Infrastructure, F. M. of T. and. (2015). Road Map for Digital Design and Construction.Introduction of modern, IT-based processes and technologies for the design, construction and operation of assets in the built environment.

Eastman, C. (2011). BIM Handbook Introduction. In BIM Handbook, A guide to building information modelling for owners, managers, designers, engineers, and contractors.

Eastman, C., Teicholz, P., Sacks, R., \& Liston, K. (2011). BIM Handbook: A Guide to Building Information Modeling For Owners. In Managers, Architects, Engineers and Contractors.

EUBIM Task Group. (2016). Handbook for the introduction of Building Information Modelling by the European Public Sector. In EUBIM Task Group.

Howard, R., \& Björk, B. C. (2008). Building information modelling - Experts' views on standardisation and industry deployment. Advanced Engineering Informatics. https://doi.org/10.1016/j.aei.2007.03.001

International Organization for Standardization (ISO). (2017). ISO/DIS 19650-1 - Part 1: Concepts and Principles. ISO 2017.

Kassem, M., Succar, B., \& Dawood, N. (2013). A proposed approach to comparing the BIM maturity of countries| NOVA. The University of Newcastle's Digital Repository. Proceedings of the CIB W78 2013: 30th International Conference. http://novaprdlb.newcastle.edu.au/vital/access/manager/Repository/uon:15200

Lindblad, H. (2019). Black boxing BIM: the public client's strategy in BIM implementation. Construction Management and Economics. https://doi.org/10.1080/01446193.2018.1472385

Mahamadu, A.-M., Navendren, D., Manu, P., Joseph, R., \& Dziekonski, K. (2017). Addressing challenges to building information modelling implementation in UK: designers' perspectives. Journal of Construction Project Management and Innovation. https://doi.org/https://hdl.handle.net/10520/EJC-af2d94e0b

McGraw Hill Construction. (2014). The business value of BIM for construction in major global 


\section{8 - 20 September, 2020 MILAN, ITALY}

markets. In SmartMarket Report.

Migilinskas, D., Popov, V., Juocevicius, V., \& Ustinovichius, L. (2013). The benefits, obstacles and problems of practical bim implementation. Procedia Engineering. https://doi.org/10.1016/j.proeng.2013.04.097

Navendren, D., Manu, P., Shelbourn, M., \& Mahamadu, A.-M. (2014). Challenges to building information modelling implementation in UK: Designers' perspectives. https://www.scopus.com/inward/record.uri?eid=2-s2.0-

84911429580\&partnerID=40\&md5=81ba8f427f53f8b1b634ff888664a7ac

NBS. (2019). National BIM Report 2019. In National BIM Report 2019 The definitive industry update. https://doi.org/10.1017/CBO9781107415324.004

Observatory, E. construction sector. (2019). Building Information Modelling in the UK construction sector.

Papadonikolaki, E., Verbraeck, A., \& Wamelink, H. (2017). Formal and informal relations within BIM-enabled supply chain partnerships. https://doi.org/10.1080/01446193.2017.1311020

PMI. (2013). Project management body of knowledge (pmbok® guide).

Pruskova, K., \& Kaiser, J. (2019). Implementation of BIM Technology into the Design Process Using the Scheme of BIM Execution Plan. IOP Conference Series: Materials Science and Engineering. https://doi.org/10.1088/1757-899X/471/2/022019

Rogers, E. M. (2003). Diffusion of Innovations, Fifth Edition. In Social Networks.

Shou, W., Wang, J., Wang, X., \& Chong, H. Y. (2015). A Comparative Review of Building Information Modelling Implementation in Building and Infrastructure Industries. Archives of Computational Methods in Engineering. https://doi.org/10.1007/s11831-014-9125-9

Silva, M. J. F., Salvado, F., Couto, P., \& Azevedo, Á. V. e. (2016). Roadmap Proposal for Implementing Building Information Modelling (BIM) in Portugal. Open Journal of Civil Engineering. https://doi.org/10.4236/ojce.2016.63040

Smith, P. (2014). BIM Implementation - Global Strategies. Procedia Engineering, 85, 482492. https://doi.org/https://doi.org/10.1016/j.proeng.2014.10.575

State, P. (2010). BIM Project Execution Planning Guide - Version 2.0. Computer Integrated Construction Research Program. https://www.bim.psu.edu/

Succar, B. (2009). Building information modelling framework: A research and delivery foundation for industry stakeholders. Automation in Construction. https://doi.org/10.1016/j.autcon.2008.10.003

Succar, B. (2010). The Five Components of BIM Performance Measurement. CIB World Congress, Salford, United Kingdom.

The Pennsylvania State University. (2013). BIM Planning Guide for Facility Owners. http://bim.psu.edu

Wu, W, Mayo, G., McCuen, T. L., Issa, R. R. A., \& Smith, D. K. (2018a). Building Information Modeling Body of Knowledge. I: Background, Framework, and Initial 


\section{$6^{\text {th }}$ International Conference On}

Modern Approaches in SCIENCE,

TECHNOLOGY \& ENGINEERING

Development. https://doi.org/10.1061/(ASCE)CO.1943-7862.0001518

Wu, W, Mayo, G., McCuen, T. L., Issa, R. R. A., \& Smith, D. K. (2018b). Building Information Modeling Body of Knowledge. II: Consensus Building and Use Cases. https://doi.org/10.1061/(ASCE)CO.1943-7862.0001536

Wu, Wei, \& Issa, R. R. A. (2014). Key issues in workforce planning and adaptation strategies for BIM implementation in construction industry. Construction Research Congress 2014: Construction in a Global Network - Proceedings of the 2014 Construction Research Congress. https://doi.org/10.1061/9780784413517.0087

Zhang, J., Schmidt, K., \& Li, H. (2016). BIM and sustainability education: Incorporating instructional needs into curriculum planning in CEM programs accredited by ACCE. Sustainability (Switzerland), 8(6). https://doi.org/10.3390/su8060525 